\title{
MJN CORRELATION OF KNOWLEDGE AND ATTITUDE ON VULVA HYGIENE PRACTICE AMONG STUDENTS OF SMPN 21 SURABAYA
}

\author{
Ni Made Wahyu Candra Purwani, Puji Hastuti ${ }^{\star}$, Astrida Budiarti, lis Fatimawati, Nur Chabibah \\ Sekolah Tinggi Ilmu Kesehatan Hang Tuah Surabaya, Surabaya, Indonesia \\ *Corresponding Author's Email: pujihastuti@stikeshangtuah-sby.ac.id
}

\begin{abstract}
Objective: The aim of the study is to determine the correlation of knowledge level and attitudes regarding vulva hygiene practicing of grade VIII students in SMPN 21 Surabaya. Methods: The design of this study is a cross-sectional observational analysis using a cluster sampling technique with sample of 138 students. Variables of the study are knowledge level, attitudes and practice of vulva hygiene. Data are analyzed using the Spearman Rho test. In this study, data are collected by questionnaire sheet. Results: The results indicate that most of the students have a sufficient level of knowledge, positive attitudes and positive behavior. The results of the Spearman Rho analysis showed that there was no correlation between knowledge level and vulva hygiene practice $(\rho=0.583)$ and there was a correlation between attitude and vulva hygiene practice $(\rho=$ 0.000 ). Conclusion: Providing information by schools through audiovisuals about reproduction organs so that the students are more interested in listening to information. Students should further increase their awareness regarding reproductive organs, especially in maintaining cleanliness to prevent adverse effects such as fungal infection and cancer.
\end{abstract}

Keywords: Knowledge Level; Attitude; Vulva Hygiene Practicing

\section{INTRODUCTION}

Adolescent problems related to reproduction organs come from a lack of information, understanding and awareness in maintaining and cleaning reproduction organs (Astuti \& Dewi, 2016). The study of Muthoharoh \& Widiyawati (2018) states that most of practice vulva hygiene during menstruation that was carried out by respondents before being given health education was negative, whereas after being given health education it showed that most of them were positive (Ristraningsih, 2017). The results of interviews conducted by researchers with students at SMPN 21 Surabaya stated that most of the students rarely dried their genitalia after urinating and the rest said they sometimes dried them. A woman with a minimum level of knowledge about reproduction health will allow unhygienic behavior during menstruation (Maidartati, Hayati \& Nurhida, 2016). Attitudes in maintaining reproduction hygiene greatly affect reproduction health, how a person behaves show how much knowledge that person also has (Notoatmodjo, 2010). Good knowledge, attitude and behavior are needed to reduce the incidence of pathological vaginal discharge (Sukamto, 2018).

In Europe, in 2013 there were 739,004,470 people and $25 \%$ of them experienced vaginal discharge (Collins et al., 2015). Women who experience vaginal discharge have an increase of $10 \%$ each year from 2010 to 2012. In 2013 from January to August, 55\% of women have experienced vaginal discharge (Rakhmawati, 2019). The results of a survey conducted on 7 students of SMPN 21 Surabaya on January 17, 2020, found that $71 \%$ of students changed their sanitary napkins up to 4 times a day, $85 \%$ of students experienced vaginal discharge, $57 \%$ of students said they did not know how to handle vaginal discharge and tended to be indifferent, $28 \%$ of students cleaned it by rinsing with water and the rest using feminine cleansing soap. The students also said that they had never received reproduction health education in their schools.

The lack of knowledge about how to maintain reproduction hygiene will have a negative impact on women's reproductive health, especially during 
menstruation (Maidartati, Hayati \& Nurhida, 2016). Poor knowledge, attitude and behavior in caring for genital organs can cause vaginal discharge such as wrong directions in cleaning, rarely changing underwear, not drying out the genitals, wearing fragrance soap and tight pants (Berliana, 2018). Infection of the reproduction organs has a negative impact on the future, such as infertility which reduces the quality of life (Muthoharoh \& Widiyawati, 2018). Another bad effect can occur in fluorine albus and cancer (Rakhmawati, 2019).

\section{METHODOLOGY}

The design of this study is a cross-sectional observational analysis using a cluster sampling technique with a sample of 138 students of class VIII SMPN 21 Surabaya. The variables of the study were knowledge level, attitudes and hygiene practice of vulva hygiene. Data are analysed using the Spearman Rho test. Data are collected by questionnaire instrument of knowledge, attitude and vulva hygiene practice questionnaire.

This research was conducted following research ethics in which researchers requested permission from related parties before the study began procedures related to research ethics, including approval letters, anonymity, confidentiality, fairness, the principle of honesty (veracity), and the principle of keeping promises (fidelity). This research has conducted an ethics test at the Hang Tuah Health College Ethics Commission with the number: $\mathrm{PE} / 8 / \mathrm{VI} / 2020$ on May 29, 2020.

\section{RESULTS}

Table 1: Responden Characteristic in Student of SMPN21 Surabaya

\begin{tabular}{|c|c|c|c|}
\hline Number & Variable & Frequency (f) & $\begin{array}{c}\text { Percent } \\
(\%)\end{array}$ \\
\hline 1 & $\begin{array}{l}\text { Menstruation } \\
\text { Yet } \\
\text { Not Yet }\end{array}$ & $\begin{array}{c}138 \\
0\end{array}$ & $\begin{array}{c}100.0 \\
0.0\end{array}$ \\
\hline 2 & $\begin{array}{l}\text { Leucorrhoea } \\
\text { Ever } \\
\text { Never } \\
\end{array}$ & $\begin{array}{c}130 \\
8 \\
\end{array}$ & $\begin{array}{c}94.2 \\
5.8 \\
\end{array}$ \\
\hline 3 & $\begin{array}{l}\text { Parent Occupation } \\
\text { Enterpriser } \\
\text { Private Employees } \\
\text { Goverment Employees }\end{array}$ & $\begin{array}{l}39 \\
76 \\
28 \\
\end{array}$ & $\begin{array}{l}28.3 \\
55.1 \\
16.7 \\
\end{array}$ \\
\hline 4 & $\begin{array}{l}\text { Parents Income } \\
<\text { Rp.4.200.000/ bulan } \\
\geq \text { Rp. } 4.200 .000 / \text { bulan }\end{array}$ & $\begin{array}{l}87 \\
51\end{array}$ & $\begin{array}{l}63.0 \\
37.0\end{array}$ \\
\hline
\end{tabular}

\begin{tabular}{|c|c|c|c|}
\hline 5 & $\begin{array}{l}\text { Health } \quad \text { Education } \\
\text { Never } \\
\text { Ever }\end{array}$ & $\begin{array}{c}11 \\
127\end{array}$ & $\begin{array}{c}5.8 \\
94.2\end{array}$ \\
\hline 6 & $\begin{array}{l}\text { Health Education } \\
\text { Source } \\
\text { Not Yet } \\
\text { School } \\
\text { Parent/Family/Friends } \\
\text { Health workers } \\
\text { Google/Youtube/Social- } \\
\text { Media/Book }\end{array}$ & $\begin{array}{c}11 \\
97 \\
14 \\
6 \\
10\end{array}$ & $\begin{array}{c}8.0 \\
70.3 \\
10.1 \\
4.3 \\
7.2\end{array}$ \\
\hline 7 & $\begin{array}{l}\text { School Toilet } \\
\text { Cleanliness } \\
\text { Not Sanitary } \\
\text { Sanitary }\end{array}$ & $\begin{array}{l}67 \\
76\end{array}$ & $\begin{array}{l}44.9 \\
55.1\end{array}$ \\
\hline 8 & $\begin{array}{l}\text { Availability of } \quad \text { Clean } \\
\text { Water } \\
\text { Available } \\
\text { Not Available }\end{array}$ & $\begin{array}{l}50 \\
88\end{array}$ & $\begin{array}{l}36.2 \\
63.8\end{array}$ \\
\hline
\end{tabular}

Table 2: Characteristics of Variable

\begin{tabular}{|l|c|c|c|}
\hline No. & Variable & Frequency (f) & Percent (\%) \\
\hline 1. & \multicolumn{3}{|c|}{ Knowladge } \\
\hline & Good & 57 & 41.3 \\
\hline & Enough & 64 & 46.4 \\
\hline & Poor & 17 & 12.3 \\
\hline 2. & & 138 & 100.0 \\
\hline & Negative & 2 & 1.4 \\
\hline & Positive & 136 & 98.4 \\
\hline & \multicolumn{3}{|c|}{ Attitude } \\
\hline 3. & \multicolumn{2}{|c|}{138} \\
\hline & Negative & 137 & 0.7 \\
\hline & Positive & 138 & 100.0 \\
\hline & \multicolumn{2}{|c|}{139.3} \\
\hline
\end{tabular}

Table 3: Correlation of Knowledge to Vulva Hygiene Practicing In Students of SMPN 21 SURABAYA

\begin{tabular}{|l|c|c|c|c|c|c|}
\hline \multirow{2}{*}{ Knowladge } & \multicolumn{4}{|c|}{ Vulva Higiene Practice } & \multicolumn{2}{c|}{ Total } \\
\cline { 2 - 7 } & \multicolumn{2}{|c|}{ Negative } & \multicolumn{2}{c|}{ Positive } & \\
\hline \multirow{2}{*}{ Good } & $\mathrm{F}$ & $\%$ & $\mathrm{~F}$ & $\%$ & $\mathrm{~N}$ & $\%$ \\
\hline Enough & 0 & 0.0 & 57 & 100 & 57 & 100 \\
\hline Poor & 1 & 1.6 & 63 & 98.4 & 64 & 100 \\
\hline Total & 1 & 0.0 & 17 & 100 & 17 & 100 \\
\hline Spearman's Rho $0.583(\rho=0.05)$ & 137 & 26.1 & 138 & 100 \\
\hline
\end{tabular}


From the results of the Spearman Rho test, it was obtained as a significant number or probability number (0.583). It can be concluded that $\mathrm{H} 0$ was accepted and $\mathrm{H} 1$ was rejected, and it's mean was no significant correlation of knowledge level to vulva hygiene practicing of the VIII grade students of SMPN 21 Surabaya.

Table 4: Correlation of Attitude to Vulva Hygiene Practicing in Students of SMPN 21 SURABAYA

\begin{tabular}{|l|c|c|c|c|c|c|}
\hline Attitude & \multicolumn{4}{|c|}{ Vulva Higiene Practice } & \multicolumn{2}{c|}{ Total } \\
\hline & \multicolumn{2}{|c|}{ Negative } & \multicolumn{2}{c|}{ Positive } & & \\
\hline & F & \% & F & \% & N & $\%$ \\
\hline Negative & 1 & 50.0 & 1 & 50.0 & 2 & 100.0 \\
\hline Positive & 0 & 0.0 & 136 & 100.0 & 136 & 100.0 \\
\hline Total & 1 & 73.9 & 137 & 26.1 & 138 & 100.0 \\
\hline
\end{tabular}

Spearman's Rho 0,000 $(\rho=0.05)$

From the results of the Spearman Rho test, it was obtained as a significant number or probability number $(0.000)$. It's mean was a significant correlation attitude to vulva hygiene practicing for VIII grade students of SMPN 21 Surabaya.

\section{DISCUSSION}

\section{Knowledge Level of Class VIII Students Regarding Vulva Hygiene Practice of SMPN 21 SURABAYA}

Table 2 shows that most of the respondents had enough knowledge (46.4\%), 57 students $(41.3 \%)$ had good knowledge, and 17 students had poor knowledge (12.2\%). This can be supported by table 6 where 127 female students $(94.2 \%)$ have received information about vulva hygiene. So, it can be concluded that the level of knowledge possessed by respondents is dominated by the level of knowledge that is sufficient.

Knowledge is the result of someone's curiosity who senses a certain object (Wahyuni \& Suparti, 2015). Through sensing carried out by a person, it will produce knowledge that is influenced by the intensity of attention and perception of the object (Notoatmodjo, 2010). A woman is very important in having good knowledge about the cleanliness of reproductive organ. If a woman lacks knowledge about the hygiene of reproductive organ, she will be susceptible to pathological vaginal discharge and if it is not treated immediately, it will cause cancer until women have decreased quality of life. Astuti \& Dewi (2016) stated that the knowledge about personal hygiene is needed so that young women understand the importance of caring for reproductive health, so that there is no risk of infection, inflammatory diseases, and infertility.

According to the researchers, 53 female students $(52.5 \%)$ had a good level of knowledge because they already had experience with reproductive organ hygiene, and when they received the information, they could immediately understand the information. Budiman \& Riyanto (2013) mentioned that experience is a factor in the level of knowledge. Experience can be used as a way to gain knowledge by repeating the knowledge gained in solving problems faced in the past. Based on the results of Ajiningsih \& Anisa (2018) from 47 respondents who had previously received information about reproductive health, 30 respondents $(63.8 \%)$ had good knowledge, and as many as 7 respondents $(14.9 \%)$ had sufficient knowledge, while the results of research from 7 respondents had never received information before, it was known that as many as 4 respondents $(57.1 \%)$ of them had insufficient knowledge.

\section{Attitudes of Class VIII Students Regarding Vulva Hygiene of SMPN 21 SURABAYA}

Table 2 shows that most of the respondents had positive attitudes - as many as 136 students $(98.6 \%)$ had a positive attitude and a negative attitude was derived from 2 students $(1.4 \%)$.

Attitude is a response to a stimulus (Wahyuni \& Suparti, 2015). Like a teenager in maintaining the cleanliness of their vulva hygiene, if she wants to have clean reproductive organs, she will show positive effects starting from simple methods such as drying them using unscented tissue after defecating.

The results of the cross-tabulation between where to get knowledge and attitudes of students showed 97 female students $(70.3 \%)$ received information on vulva hygiene in schools, 95 students $(97.9 \%)$ had positive attitudes and 2 students $(2.1 \%)$ had negative attitudes in keeping their vulva hygiene clean. According to researchers, educational institutions affect the attitude of a teenager because that is where good and bad understanding is formed and also most of the time the students spend in a day is at school. Astuti (2013) states that there are 6 factors that influence attitudes including the influence of other people, mass media, and educational institutions.

Researchers assume that 2 students $(2.1 \%)$ who have negative attitudes in maintaining vulva hygiene 
can be caused by the influence of their emotional factors in which students are a category of early adolescents who still have unstable emotions. Another assumption, according to the researchers, is that students have less personal experience related to the hygiene of reproductive organs, which results in them not being able to determine their attitudes in a positive or negative direction. Results of cross-tabulation between vaginal discharge experiences to attitudes showed that 8 students $(5.8 \%)$ stated that they had never had vaginal discharge, and 1 student had a negative attitude. Astuti (2013) revealed personal experience that one of the factors that influence individual attitudes is personal experience shapes a person's appreciation of social stimuli and will shape their attitudes. Attitudes are formed from cognitive, emotional, and behavioral components that shape a person's personality (Donsu, 2019). Experience also affects the attitudes shown by students in maintaining the cleanliness of their vulva hygiene because experience can leave a distinct impression on someone who will shape their attitude in a positive or negative direction. According to Cahyo (2011) experience greatly affects a person's attitude. The more experienced someone is, he/she will have a positive attitude.

\section{Practice Vulva Hygiene Cleanliness of Class VIII Students on SMPN 21 Surabaya}

Table 2 shows that most of the respondents had positive behavior in their vulva hygiene for 137 students (99.3\%), and negative behavior was derived from 1 student (0.7\%). Donsu (2019) defines behavior as the action of an organism that can be observed and can be studied. The results showed that most of the students had positive behavior in maintaining the cleanliness of their vulva hygiene. According to the researchers from knowledge and attitudes, behavior is something that can be concluded directly that the behavior is good or bad. This is in accordance with the theory of Donsu (2019) and it states that behavior is an action that can be observed and can be learned.

According to the researchers, as many as 137 students $(99.3 \%)$ had a positive behavior in maintaining the cleanliness of their vulva hygiene because students already have three factors that can support their health behavior, namely a good level of knowledge, having easy means of having positive behavior in keeping their vulva hygiene have skills in maintaining health, and have a supportive environment in understanding the importance of maintaining the cleanliness of the reproductive organs. In Lawrance Green's theory, there are factors that influence health behavior, including knowledge, attitudes, beliefs, supporting factors that allow someone to carry out health behaviors including health facilities, and finally the driving factors, namely factors that reinforce the existence of health behavior include family, teachers, friends, and health workers.

4. The Relationship between Level of Knowledge and Vulva Hygiene Behavior for Class VIII Students of SMPN 21 Surabaya

Table 3 shows that relationship between knowledge level and the vulva hygiene behavior of students of class VIII SMPN 21 Surabaya from 138 students. It shows that 57 respondents have a good level of knowledge, 0 respondents $(0.0 \%)$ have negative behavior in maintaining vulva hygiene, 57 respondents $(100.0 \%)$ have positive behavior in maintaining clean vulva hygiene. From the 64 respondents have a sufficient level of knowledge, 1 respondent (1.6\%) had negative behavior in maintaining vulva hygiene, and 63 respondents $(98.4 \%)$ had positive behavior in maintaining vulva hygiene. And from 138 respondents, 17 respondents have a low level of knowledge about vulva hygiene, with 0 respondents $(0.0 \%)$ having negative behavior and 17 respondents $(100.0 \%)$ having positive behaviors.

The results of data analysis show that most of the students have a sufficient level of knowledge and positive behavior of vulva hygiene. The results from Spearman Rho Test show that there was no relationship between the level of knowledge and vulva hygiene behavior of the VIII grade students of SMPN 21 Surabaya with $\rho$ value $=0.583$. This corresponds to research conducted by Rakhmilla et al. (2016) shows that there was no relationship between the level of knowledge of young women in maintaining the cleanliness of genitalia and the incidence of vaginal discharge with a significant level value of 0.628 . There was no relationship between the knowledge and the practice of vulva hygiene and the incidence of vaginal discharge. The research also showed that there was no correlation between knowledge and the incidence of vaginal discharge (Azizah \& Widiawati, 2015).

The problems found in respondent knowledge about vulva hygiene, namely regarding underwear, can be seen from one of the lowest results in question number 6 , namely regarding the right underwear material every day as many as $32.6 \%$ of respondents answered 
questions with wrong statements. Here the researcher assumes that the respondents are not well informed about materials that are good for their underwear. The cross-tabulation of students' experiences of health education and their level of knowledge revealed that 127 students $(92.0 \%)$ had received health education and 59 students $(46.5 \%)$ had a suitable level of understanding. Researchers assumed that as many as 59 students $(46.5 \%)$ stated that they had received information about vulva hygiene but had a sufficient level of knowledge that it could be possible because students had less interest in the information conveyed and the ability to absorb information received was low. Another assumption was those who felt they had received information about vulva hygiene in school, but still had a low level of knowledge, because when the information was given, they did not focus on responding to the information. This is also supported by the results of the cross-tabulation between the places receiving health education and the level of knowledge of vulva hygiene, it was found that most of the 97 students $(70.3 \%)$ stated that they had received health education in schools with 48 students $(49.5 \%)$ having a sufficient level of knowledge. The learning process is influenced by several factors from internal, such as motivation, and external factors such as the form of available information facilities, as well as sociocultural conditions (Budiman \& Riyanto, 2013). There can be concluded that the majority of students who receive health education at school have poor absorption of information and it could be possible that students are not interested in the material provided by the teacher due to a lack of student motivation. According to Astuti \& Dewi (2016), the lack of knowledge about reproductive organ hygiene of students can occur because students do not get information from various sources such as print and electronic media as well as lack of socialization and counseling about personal hygiene of reproductive organs in schools.

\section{The Relationship between Attitude and Vulva Hygiene Behavior for Class VIII Students of SMPN 21 Surabaya.}

Table 4 shows the relationship between the attitudes and the vulva hygiene behavior of students of class VIII SMPN 21 Surabaya from 138 students, showing that of the 136 respondents had positive attitudes. There were 0 respondents $(0.0 \%)$ having negative vulva hygiene behavior and 136 respondents $(100.0 \%)$ had negative behaviors, and 2 respondents are having negative attitudes, with 1 respondent $(50.0 \%)$ having negative behavior and 1 respondent $(50.0 \%)$ having positive behavior in maintaining clean vulva hygiene.

From the results of data analysis, it can be concluded that most of the students have a positive attitude and most of the students have good vulva hygiene behavior. Based on the results of the Spearman Rho test, a significant number or probability $(0.000)$ is obtained, it can be concluded that $\mathrm{H} 0$ is boxed and $\mathrm{H} 1$ is accepted, which means there is a relationship. There is a significant difference between attitudes and the vulva hygiene behavior of the student VIII class of SMPN 21 Surabaya. This is in line with the study of Wisnatul \& Agustiani (2014) which showed that there was a correlation between attitudes about menstrual personal hygiene and personal hygiene behavior for girls during menstruation $(\rho=0.000)$.

An attitude is a form of one's readiness to react to an object in a certain way. Readiness in question is the tendency for potential reactions that will occur in the ways that an individual has if a person is faced with a certain stimulus which requires a response which means positive effect (supporting the object), then the opposite if someone does not want a response which means negative effect (refused response) (Azwar, 2013).

According to the researchers, most of the students who have a positive attitude in maintaining the cleanliness of their vulva hygiene already have a good acceptance of the experiences they experience such as the experience of vaginal discharge. They want to learn from this experience, and ultimately it can affect their personality and behavior in dealing with vaginal discharge. Budiman \& Riyanto (2013) states that there are five levels of attitude, namely accepting which means that someone has a willingness to accept an object, responding which means someone has responded to an object, assessing which means someone has given their assessment of an object, managing which means someone has found a difference in value from an object and live, which means that someone has been affected by an object and has her system that will control his pattern of life.

Another assumption is that there is students' interest in using school toilets because the data obtained from the results of cross-tabulation between the existence of clean toilets in schools with a scrap shows that 76 students $(55.1 \%)$ stated that their school toilets were clean, as many as 74 students (97.4\%) had positive 
attitudes, which means that most respondents stated that their school toilets are clean and have positive behavior. This can increase students' interest in maintaining their vulva hygiene behavior, for example changing sanitary napkins 3-4 times a day, where most of the time they spend is at school. The results of Permatasari (2018) research show that there is a relationship between the availability of facilities and facilities on the behavior of caring for the hygiene of reproductive organs. Because the availability of facilities and facilities will support the interest of young women to maintain the behavior of maintaining the cleanliness of the reproductive organs, it is very appropriate if they are available in a school and living environment (Humairoh, Musthofa \& Widagdo, 2018).

\section{CONCLUSION}

The results of this study show that most of the students have a sufficient of level knowledge, positive attitudes and positive behavior. The results of analysis the Spearman Rho test showed that there was no correlation between the knowledge level and vulva hygiene behavior $(\rho=0.583)$, and there was a correlation between attitudes and vulva hygiene behavior of students of class VIII SMPN 21 Surabaya r $(\rho=0.000)$. There is a need to conduct further research about other factors related with vaginal discharge and further studies are necessary with more samples.

\section{Conflict of Interests}

The authors declare that they have no conflict of interests.

\section{ACKNOWLEDGEMENT}

The authors are thankful to the headmaster and students of SMPN 21 Surabaya, as well as all parties involved in the research process who cannot be mentioned one by one.

\section{REFERENCES}

Ajiningsih, D. A., \& Anisa, D. N. (2018). Hubungan Pengetahuan Dengan Sikap Remaja Tentang Kesehatan Reproduksi Di SMP PGRI Kasihan Yogyakarta. Universitas 'Aisyiyah. http://digilib.unisayogya.ac.id/4334/ 1/NASKAH\%20PUBLIKASI\%20\%28DWI\%20ASTUTI\%20AJININGSIH\%29.pdf

Astuti P. L., \& Dewi, N. S. (2016). Hubungan Tingkat Pengetahuan Remaja Putri Dengan Perilaku Personal Hygiene Organ Reproduksi Di Smp Negeri 3 Kendal. Journal Ilmu Kesehatan, 6(1), 34-37.

Astuti, S. (2013). Hubungan Tingkat Pengetahuan dan Sikap Masyarakat terhadap Upaya Pencegahan Penyakit Tuberkulosis di RW 04 Kelurahan Lagoa Jakarta Utara Tahun 2013. Universitas Islam Negri Syarif Hidayatullah. https://repository.uinjkt.ac.id/dspace/bitstream/123456789/24321/1/SUMIYATI\%20ASTUTI-fkik.pdf

Azizah, N., \& Widiawati, I. (2015). Karakteristik Remaja Putri Dengan Kejadian Keputihan Di Smk Muhammadiyah Kudus. Journal Ilmu Keperawatan Dan Kebidanan, 6(1), 57-78.

Azwar, S. (2013). Sikap Manusia : Teori dan Pengukurannya (2 ${ }^{\text {nd }}$ ed.). Pustaka Belajar.

Berliana, P. R. (2018). Hubungan Perilaku Vulva Hygiene Dengan Kejadian Keputihan Di SMP 2 Mejobo Kudus. Prosiding HEFA, 2(1).

Budiman, \& Riyanto, A. (2013). Kapita Selekta Kuesioner: Pengetahuan dan Sikap dalam Penelitian Kesehatan. Salemba Medika.

Cahyo, A. S. (2011). Hubungan Antara Tingkat Pengetahuan, Sikap Dan Ketersediaan Sumber Dengan Perilaku Remaja Putri Dalam Menjaga Kebersihan Organ Genitalia Untuk Mencegah Keputihan di Madrasah Aliyah Negeri 2 Pati. Journal Keperawatan, 4(1), 60-74.

Collins, S., Beigi, R., Mellen, C., O'Sullivan, D., \& Tulikangas, P. (2015). The effect of pessaries on the vaginal microenvironment. American Journal of Obstetrics and Gynecology, 212(1), 60.e1-60.e606.

Donsu, J. D. T. (2019). Psikologi Keperawatan. Pusaka Baru Press.

Humairoh, F., Musthofa, S. B., \& Widagdo, L. (2018). Faktor-Faktor Yang Mempengaruhi Perilaku Vulva Hygiene Pada Remaja Putri Panti Asuhan Di Kecamatan Tembalang, Kota Semarang. Journal Kesehatan Masyarakat, 6(1), 
$745-752$.

Maidartati, M., Hayati, S., \& Nurhida, L. A. (2016). Hubungan Pengetahuan Dengan Perilaku Vulva Hygiene Pada Saat Menstruasi Remaja Putri. Journal Ilmu Keperawatan, IV(1), 50-57.

Muthoharoh, S., \& Widiyawati, R. (2018). Pengaruh Health Education Terhadap Perilaku Vulva Hygiene Saat Menstruasi Anak Sd Umur 11 - 13 Tahun Di Sdn Mojosari Kabupaten Mojokerto. Journal Nurse and Health, 7(1), $61-70$.

Notoatmodjo, S. (2010). Promosi Kesehatan dan Ilmu Perilaku. Rineka Cipta.

Permatasari, N.Z. (2018). Praktik vulva hygiene pada remaja putri di pondok pesantren putri nurul burhany Mranggen kabupaten Demak. Universitas Muhammadiyah Semarang. http://repository.unimus.ac.id/2555/43/ MANUSKRIP.pdf

Rakhmawati, D. (2019). Hubungan Tingkat Pengetahuan Remaja Putri Tentang Vulva Hygiene dengan Kejadian Keputihan di SMP Muhammadiyah 1 Yogyakarta. Thesis, University of 'Aisyiyah Yogyakarta.

Rakhmilla, L. E., Fah, L. I., Sofiatin, Y., Widjadjakusuma, A., \& Rosyada, N. A. (2016). Knowledge, Attitude, and Practice about Vaginal Discharge on School-Age Girls in Jatinangor Senior High School. Open Access Library Journal, 3(11), 1-9.

Ristraningsih, G. (2017). Pengaruh Pendidikan Kesehatan Terhadap Tingkat Pengetahuan Kesehatan Reproduksi Remaja Pada Siswi Kelas VIII Di Smp Negeri 28 Semarang. Thesis, University of Muhammadiyah Surakarta.

Sukamto, N. R. (2018). Hubungan Pengetahuan, Sikap, Dan Perilaku Perawatan Vagina Terhadap Kejadian Keputihan Patologis Pada Mahasiswi Program Studi Pendidikan Dokter Fakultas Kedokteran Universitas Sriwijaya. Universitas Sriwijaya. https://repository.unsri.ac.id/4513/1/RAMA_11201_04011181520079_004108106_ 0005025209_01_font_ref.\%20pdf.pdf

Wahyuni, S., \& Suparti, S. (2015). Hubungan Pengetahuan Dengan Sikap Mahasiswi Tingkat I Tentang Vulva Hygiene Di Akbid Mamba'ul 'Ulum Surakarta Tahun 2015. Journal Kebidanan Indonesia, 6(2), 117-130.

Wisnatul, I., \& Agustiani, R. (2014). Hubungan Pengetahuan Dengan Pelaksanaan Personal Hygiene Genitalia Saat Menstruasi Pada Remaja Putri Kelas Ix Smp Negeri 4 Bukittinggi. Journal Ilmu Kesehatan 'Afiyah, 2(1). 